This item was submitted to Loughborough's Research Repository by the author.

Items in Figshare are protected by copyright, with all rights reserved, unless otherwise indicated.

\title{
New Labour, racism and 'new' football in England
}

PLEASE CITE THE PUBLISHED VERSION

http://dx.doi.org/10.1080/00313220500482704

VERSION

AM (Accepted Manuscript)

\section{PUBLISHER STATEMENT}

This work is made available according to the conditions of the Creative Commons Attribution-NonCommercialNoDerivatives 4.0 International (CC BY-NC-ND 4.0) licence. Full details of this licence are available at: https://creativecommons.org/licenses/by-nc-nd/4.0/

LICENCE

CC BY-NC-ND 4.0

\section{REPOSITORY RECORD}

Bradbury, Steven, and John Williams. 2019. "New Labour, Racism and 'new' Football in England". figshare. https://hdl.handle.net/2134/24538. 
New Labour, racism and 'new' football in England

STEVEN BRADBURY AND JOHN WILLIAMS

ABSTRACT Bradbury and Williams begin by examining aspects of the genealogy of incidents of fan racism at the Spain v. England international football match in Madrid on 17 November 2004 , and the public outcry in Britain that followed. They raise questions about the possible 'strategic mobilization' by Spanish fans of apparently racist epithets as a response to the use, by the English football authorities before the match, of prominent anti-racism symbolism. The main body of the article then considers the British public response to Madrid within the context of the Blairite New Labour policy on football racism in England from the late 1990s. It argues that Labour's Football Task Force from 1997 constituted an entirely new direction for sport and government policy in Britain. However, by drawing on the comments of some of the key figures involved, Bradbury and Williams further contend that, both structurally and ideologically, the Task Force was preset to limit its own investigations on the nature and effects of racism, specifically in the English game. Although the Task Force's report, Eliminating Racism in Football, has had some positive effects, for example, on Football Association policy or in stimulating local anti-racist initiatives, its narrow focus and its relatively underdeveloped understanding of the racism problem in professional sport led its members to de-emphasize the significance of forms of institutionalized racism within English football. Research and commentaries on racism in the English game since that report was published in 1998 suggest that problems of racialized exclusion in football remain. Bradbury and Williams conclude that the public outrage in Britain about the incidents in Madrid reflect an over-concentration on silencing public expressions of racism, combating overt collective fan outbreaks at the expense of addressing the racialized structures of power that continue to shape access, opportunities and acceptance of ethnic minorities within professional football in England.

KEYWORDS English football, fan racism, Football Task Force, governance, institutional racism, New Labour, normative whiteness, racism, Third Way

One (racist?) night in Madrid

In October 2004, while preparing for a friendly international football match between Spain and England in Madrid on 17 November, the sixty-nine year- old Spanish team coach, Luis Aragones, was captured on Spanish television during training trying to 'motivate' his young striker Jose' Antonio Reyes by urgently insisting to the Spaniard that he was even a better player than his Arsenal club colleague, the celebrated Frenchman Thierry Henry. According to Aragones and the television microphones Henry was no more than a negro de mierda, a 'black shit'. This incident, initially, excited little public attention in Spain, where sensitivities about language and racism seem to be much less excitable than in Britain. The Spanish sports daily AS, for example, had previously, without critique, described Real Madrid's hardworking, white midfielder Guti as 'running like a black man', and the English, rather perceptively perhaps, as 'very serious when it comes to race, politically correct in the extreme, which is also a way of hiding their own defects'.Moreover, the elderly Aragones was, it was alleged, widely viewed in Spain as atavistic and unrepresentative of the Spanish people: a 'silly, insensitive, old blunderer, a child of the Franco era of whom such crassness 
is almost to be expected'. In short, it was claimed, this was a (racist) storm in a sporting Spanish teacup. But in England football officials and anti-racist campaigners were evidently shocked by the Aragones incident and when the England squad including Real Madrid's own English stars, David Beckham and Michael Owen trained in Spain before the friendly fixture they, pointedly wore distinctive Kick It Out anti-racism campaign t-shirts for Spanish television and press coverage. Aragones's later pre-game press conference degenerated into a slanging match in which the coach denied English charges of racism, and raised, instead, the subject of England's own colonialist past and compared the British press pack to 'wolves'. Aragones certainly had his domestic supporters: the Spanish state television network TVE reported, archly: 'The British press have looked to cause a storm. They were determined to get Aragones and they've succeeded. Ironically, football's European governing body Uefa's determination to advertise its own anti-racism credentials on screens and advertising boards before the Spain/England match seemed only to add fuel to the fire. 'Gorilla' chants and hooting directed at England's black players, initially emerging, allegedly, from a small group of Real's far-right Ultra-Sur fans, soon spread to other, more well-heeled, Spanish supporters, including men, women and children. Thousands began bobbing and singing: 'Whoever doesn't bounce is fucking black.' Even Spanish police officers were reported to have joined in. These events, predictably, provoked an international flurry of comment and condemnation. Some regular football observers in Spain claimed never before to have experienced such a collective show of racism in the Spanish game, while others argued that this display was simply an unreported 'weekly ritual' in club stadiums throughout the country (5). Explanations for the Madrid outburst similarly diverged: from structural theses, citing a recent surge of immigration to Spain and the destabilizing and marginalizing effects of the growing rootlessness and alienation produced by globalization, 6 to the importance of much more immediate triggers, including the 'arrogant hypocrisy' of the English and their prior, very public, attacks on Spanish football and its national coach. In these latter accounts, 'racism', it was argued, had been mobilized, mainly strategically, as a means of reasserting national solidarity and as a response to English cant and decades of England exporting their own xenophobic hooliganism.7 In England, meanwhile, predictable tabloid outrage over Madrid was matched by some rather more reflective accounts in the broadsheet press, some suggesting direct action*/leaving the field*/should have been taken by the English players and officials. 8 Other, rather more self-congratulatory, accounts argued that successful policies opposing racism in English football had actually served to undermine racism elsewhere in Britain. 9 Still others warned about the dangers of assuming the moral high ground, claiming that, while racism in English football may be suppressed in crowds at the higher levels, it continues to pervade the sport. The sociologist Ernest Cashmore pointed out, for example, that fans in England had been forced to accommodate change and that a 'fragile, conditional concordance' had recently emerged in the English game, one in which the celebrity status of top, imported black players now shielded them from racism, but did little to spare 'nondescript black players from the lower divisions'.10 Ex-England internationals John Barnes and Paul Davis reported that racism in the English game continued to impact negatively on their post-playing careers, and Fulham's Luis Boa Morte claimed that there was plenty of overt on-field racism in today's Premiership, the highest level of club football.11 Moreover, soon after the events in Spain, the Blackburn Rovers and Trinidad striker Dwight Yorke complained that he was racially abused by fans as he had warmed up for a match in Blackburn: 'monkey' chants, similar to those identified in 
Madrid, were to the fore. Crude abuse of black players by spectators was, clearly, no stranger to the 'post-racist' English Premiership.12

With no Spanish equivalent of the UK's Commission for Racial Equality, and no anti-racism initiative for football in Spain, the British government demanded*/and eventually got*/an apology from the Spanish Prime Minister for the events at the Bernabeu stadium. Fifa, the governing body of world football, eventually fined the Spanish Football Association $£ 44,750$ for the affair, a punishment described by English anti-racism campaigners as 'a slap on the wrist'.13 A spokesperson for Tony Blair commented that the British Prime Minister 'believes that racism has no part to play in sport*/or anywhere else for that matter. We believe we have made real progress in kicking racism out of British football.'14 This reported 'progress' on racism in football was the basis for the response in Britain over matters in Madrid. Blair, rather strangely here, fuses English domestic football with the game in Scotland, Northern Ireland and Wales. But exactly how much had really changed in England? Certainly, overt, collective fan racism was now less common in the English game than it had been in the past. New Labour had sought changes in this area by encouraging re-energized links between the professional game and local communities and by adopting a more 'interventionist' approach towards the issue of football's wider social responsibilities, including its public role in England in combating racism. But how successful had New Labour actually been in this regard? And how appropriate a mechanism had Labour's chosen vehicle, its innovative Football Task Force, been for addressing specifically English football's racism problems? Before considering these questions in more detail we want, first, to say something about the history of relations between football and the Labour Party in Britain and to comment briefly about aspects of the so-called 'cultural reinvention' of English football in the 1990s.

Labour, popular culture and English football: some history

The social and historical development of professional football in Britain and the Labour Party share significant features in that they are both rooted in working-class formations and experience. Because of the historical tendency for Labour to draw its electoral support from working-class communities, 15 and for early English clubs to be situated in working-class locales and draw heavily on such communities for patterns of active support, it is perhaps unsurprising that the term 'the Labour Party at prayer' has been coined to describe football crowds during the 'early modern' era of the professional game.16 Even the offices of the professional Football League were situated in Labour strongholds in the industrial north, in order to counter the southern, public school and 'amateurist' leanings of the early established elites at the London-based Football Association (FA).17 But, while the symbolism of English football was politically significant, the game in England, typically, eschewed direct political involvement at both local and national levels.18 This certainly applied to the Labour movement in Britain throughout the greater part of the twentieth century: Labour politicians were generally content with the FA's control of the game and with English sport's resolutely 'non-politicized' focus for national unity.19 They typically displayed 'a recognition that neither the resources nor the social climate existed for football to be "socialized" properly'.20 The Labour Party and professional football in Britain have also experienced remarkably similar and, seemingly, parallel trajectories. In the immediate aftermath of the Second World War, football attendances in England peaked almost at the same time as did the Labour popular vote; they then both declined, with brief upturns for 
both football and Labour in the modernizing 'white heat' Harold Wilson era of the 1960s, when England also won the Fifa World Cup for the only time.21 This high point for English football was followed in the post-1960s period by its low point of declining crowds, fan hooliganism, racism, poor spectator facilities and muddled and divided management. The popularity of the Labour Party declined too*/and dramatically so*/following its troubled adminstrations of the 1970s, and its enforced period in political opposition in Britain throughout the 1980s and early 1990s. English football's recent late-modern 'revival' arguably began, institutionally, with the reformist recommendations of the Taylor Report following the Hillsborough stadium disaster in 1989,22 but it was confirmed by the emergence in 1992 of the highly marketed FA Premier League, with its television riches, new stadiums and global player rosters.23 The beginning of a major cultural shift in the sport's fortunes in England can probably be traced to the 1990 World Cup finals in Italy, when the England team, and even its fans, already written off as deriving from a culture that was 'all played out', instead captured the English sporting imagination.24 England eventually succumbed to Germany, but only in a semi-final penalty shootout in Turin. Moreover, the rather more textured and benign vision of the sport offered by television coverage of Italia '90*/opera, wonderful stadiums, groomed and honed athletic sporting bodies, tearful England heroes*/was certainly important for shaping the new consumption and marketing of football in England in the 1990s. But Italia '90 also signalled important new developments along the sporting fissures of 'race'. New black influences in world football emerged in Italy in 1990, for example, perhaps especially in the shape of the previously unconsidered African champions from Cameroon. The Africans lost unluckily to a genuinely popular and successful multiracial England team, which itself offered a new symbolic challenge to 1980s images of collective racist abuse and far-right activity among some travelling England football fans, if not barely concealed racism among the game's officials in England. By now, players such as John Barnes, Paul Parker and Des Walker regularly featured for England under manager Bobby Robson, a fact that provoked reported concern, on the part of some FA council members present in Italy, that 'too many' black players were now playing for the national team. 25 However, the cultural epiphany for the 'new' England had actually begun earlier in 1990 when the intensely fashionable and culturally 'white' Manchester-based rock band New Order recorded 'World in Motion', the official England tournament song. This unprecedented music/style/football synergy centred on the contribution of the culturally complex figure of Jamaican-born Liverpool and England winger John Barnes, and drew heavily on modes of stylistic expression closely associated with the African- American influenced hip-hop and dance music genres that were now increasingly popular with a youthful and multicultural British audience. The revival of English football's fortunes in the 1990s was mirrored by the successful rise of New Labour, which was quick to seize on key elements of Britain's rejuvenated fashion, music and sports*/most notably, football*/ industries in order to elaborate a political thematic centred around youthful dynamism and the trope of 'modernization'. The rhetoric of New Labour's election slogan for 1997*/'Labour's Coming Home'*/was itself appropriated from the laddish comedians David Baddiel and Frank Skinner's popular celebration in song*/'Football's Coming Home'*/of English football heritage and nationhood, which came to signify the collective euphoria surrounding the Euro ' 96 football tournament that England successfully hosted.26 In the post-Fordist and Blairite 1990s, the relationship between professional football in England and New Labour produced*/symbolically, at least*/a powerful and seductive synergy. But 
how did the 'cultural reinvention' of both Labour and football in the 1990s translate into more direct policy intervention designed to shape the future direction of the game away from its racist past? The answer was that Labour's new Football Task Force would be charged with devising strategies to 'eliminate' racism from English football. It was a tough assignment.

New Labour and 'new' football

As 'new' football's successful, market-driven programme of modernization of the 1990s began to quell hooliganism and seemed to chime, increasingly loudly, with New Labour's own irreducible beliefs in the efficacies of the social market, Tony Blair, even before the 1997 general election, had been expanding on his party's plans to re-examine 'regulation' issues in football and to extend the role of fans within the sport.27 Just as the new neoliberal football entrepreneurs who were leading the cultural and economic transformation of football in England in the early 1990s sought to liberate the sport from the cultural and psychological baggage that accompanied, according to the FA's own Blueprint for Football in 1991, its heavily masculinized (and racialized) ties of class, place and tradition, so the Labour Party was assiduously 'updating' its own image and 'branding', especially in terms of its preferred relationship between markets, managers and governance. In short, and in the wake of successive and damaging electoral defeats, Labour adopted a rhetoric and policy focus much more consistent with the new post-Fordist times. As Ruth Levitas points out: 'The embedded market and the strong society of New Labour replace[d] the free market and the strong state of Thatcherism.'28

Just as elite professional football in England had disengaged, relatively speaking, from its established fan constituencies*/and certainly from its troubled recent past*/so, it was argued, the Labour Party would need to escape its own electoral shackles by dumping old alliances, among them its close relations with the trade unions, its traditional (and limiting) reliance on a strong base of white, working-class, male support, and its claims to represent such interests, in the name of a more egalitarian social order. In their pragmatic appeal to 'accessible classlessness' or the 'new sociology of aspirations',29 both football and New Labour would now de-emphasize contacts with their old supporter bases and go, aggressively, in search of influential new 'customers'. By the late 1990s, with culture, according to some, now out-performing politics in providing new narratives and representations of nationality and modernity, 30 Blair was quick to seize on Premiership football as part of the rebranding of the party as youthful, multicultural, modern and progressive, even though ideas about the 'national popular'*/expressed, for example, through Euro ' $96 * /$ run the risk of offering conservative and spatially confined forms of localized and racialized exclusion.31 Following a series of meetings with the English game's governing bodies and fan organizations, a Labour blueprint emerged that promised radical change in football: Labour's Charter for Football. In this, New Labour promised, once elected, to establish an interventionist Football Task Force that would:

'initiate a new framework to introduce much needed change into the structure ofour national game. In tandem with this new development Labour will set an example, ensuring that its own responsibilities are met once in government. We will implement a range of specific measures aimed at improving all aspects of football'.32 
Labour's Task Force would address seven key issues in the English game: matters of racism and exclusion; disability access; community issues and players as role models; greater supporter involvement in the running of the game; ticketing and pricing policies; merchandising policies; and the need to reconcile the legitimate needs of shareholders and supporters where clubs had been floated on the stock exchange. This 'shopping list' for reform risked depicting racism as, merely, one of a long list of similar 'projects' or 'difficulties' that could, largely, be resolved by negotiation, and within the game itself. Nevertheless, the willingness of New Labour to engage with football in this way arguably marked a new era in the intercourse between politics, culture and sport in England. In contrast to the almost phobic relationship the Tories, under Margaret Thatcher, had had with football, New Labour at least seemed to reposition the game as a central feature of the national sporting and cultural fabric, even if some fans suggested that political expediency*/for example, linking sleaze in football with Conservative Party improprieties $33 * /$ rather than issues of anti-racism or social inclusion in sport, might actually be rather closer to the heart of Labour's new politics/football agenda.

Labour's 'big tent': the Football Task Force

In the autumn of 1997 Labour's Football Task Force was launched, made up of the key 'stakeholders' within the game, including representatives from the FA, the Premier League, the Football League, the Professional Footballers' Association and fan organizations. In total, fifteen different football-related organizations were involved and other interested parties were added to the group at various points during the project. Only one main Task Force member was black*/the referee Uriah Rennie*/and none were of South Asian origin. 'Diversity', in this context, clearly referred to varied sporting and political allegiances and not ethnic origin, because in line with the 'big tent', or third sector, consensus politics of Blairism, former Conservative MP and disgraced cabinet minister David Mellor was chosen to chair the Task Force. Mellor's appointment was strategic, of course. It would help mask any possible external perception that the Task Force might signify direct state intervention in the 'private' business of football. And, of course, it would also safely distance the government in the event of a perceived failure of the new body to deliver on any of its stated aims. It was hard to deflect accusations, in any case, that the Task Force would soon become a highprofile*/ and divided*/talking shop. Mellor, himself, certainly seemed unimpressed by the group's agenda, describing it as the outcome of 'throwing a handful of pieces of paper with issues on them into the air and seeing which ones landed first'.34 From the outset, the new Task Force was poorly resourced and its status was unclear. Could it make policy? What commitment would government and other agencies make to put into effect its recommendations? This loose alliance and fusion of competing interests also alluded strongly, of course, to the centrist Blairite 'prescriptive communitarianism', promoted by the theories of Anthony Giddens and others. 35 Its effects had already been manifest in the increasing number of government-directed quangos and the general favouring of the 'governance at a distance' approach and the promotion of 'stakeholder' agendas. The Task Force was explicitly not about government interventionism at all, in fact, or about corporatist or legislative change. It was premised, instead, on a kind of social osmosis that 'does not rely on new rules or regulations or new acts of Parliament', but is 'about creating a change in culture in the country'.36 Task Force critics argued that the attempt to secure any sort of consensus between representatives with such polarized 
interests and views, such narrow 'ethnicity' credentials and ideologies, and such varying degrees of access to power and resources was a recipe for merely tinkering with the status quo. Under such conditions, how could the Task Force make meaningful policy directives on football racism? The identification of the seven key areas defined as needing 'immediate investigation'*/to result in four reports that would include recommendations to the government and football authorities*/and of the government's preference for consensus over prescription marked a considerable shift in emphasis from the sharply focused and bullish agenda laid out by Labour, when out of office, in the Charter for Football. In short: 'It seemed that Labour's commitment to grasp the football nettle had certainly diminished since coming to power.' 37 It is also clear that the preference of government at the outset was for the football authorities to develop modern and efficient structures of self-regulation on the basis of consultation with all of the game's established stakeholders. As Andy Burnham, a former Football Task Force administrator and today the Labour MP for Leigh and a key figure on the All-Parliamentary Football Group, observed:

'In essence it was 'third way'. ... [Y]ou have a stakeholder Football Task Force because you are saying to that sector: 'Come together with your own solution.' They [the people in the game] had failed to tackle these seven problems, hence the government was pulling them around a table... By its very nature it was a self regulatory measure. So when people talk about the Football Task Force recommending an OFF-FOOT or a regulator, quite honestly, that was never going to happen. They [the football authorities] were not going to vote for it. They were not going to recommend something that the vast majority of them didn't Want'.38

Despite divisions and strains inside the Task Force caused by intra- and inter-organizational tensions deriving from ongoing power struggles both within the FA and between the main football bodies, 39 it eventually produced its four reports covering: facilities for disabled fans; 'community' issues; 'commercial' policy; and, first of all, the report Eliminating Racism from Football. For Andy Burnham, the difficult process of evidence gathering, holding wideranging consultations and seeking consensus across contentious boundaries, where dialogue and exchange were hardly normal practices, turned out to be a dynamic and productive process unique in the history of the sport. For all its problems, the Task Force, he argued, could highlight fresh challenges and questions for the English football industry.

'Consensus was extremely difficult to reach. Going from the extreme*/normally from the Football Supporters Association, who I had most sympathy with*/to the most reactionary*/and they won't thank me for saying this, but it was probably the FA. And it was great to see that clash of perspectives and ideologies. ... In a way, the Task Force began dialogues that simply were not happening in football. . . I think as far as Tony Banks [Minister for Sport] was concerned he was very keen to just let it all hang out and let the flak happen because that was a creative thing. Going back to how we agreed the reports: very painful, very difficult, [a] fractious process, because everyone realized they had to come up with something. You know, that's what made it great'.40

Fans' representatives on the Task Force saw things rather less positively, arguing that its meetings were 'something of a political battleground', in which the 'lines of communication between the Premier League, the FA and those running the Task Force put them at an 
advantage [over fans], without doubt'.41 However, despite a generally very mixed public response to the Task Force and its role, 42 broadly speaking, its work on both racism and on disability produced more internal consensus than on other matters and was also better received outside, perhaps suggesting that no important oppositional schisms, major financial questions or key issues of power and control in the game were perceived by Task Force members*/or by the British white majority outside*/to be at stake in these areas. By contrast, the final report on 'commercial' issues defied any sort of collective Task Force agreement at all.43 For Andy Burnham, the Task Force represented 'progressive change, not a big bang, but a steady process', 44 while for the players' union chief executive, Gordon Taylor, it was simply a 'missed opportunity for government'. 45 Fans' representative Adam Brown contends that it was actually government refusal to act positively on the basis of Task Force conclusions that lay at the heart of its relative failure.

'The real tragedy is that the government was toothless, not that the Football Task Force was toothless. Because the Task Force made recommendations to the Minister for Sport and the Secretary of State and it was their responsibility to act upon them. They steadfastly refused to do anything that offended the football authorities'.46

Having established some context and looked, briefly, at the mechanics of setting up the Task Force and at some critics of its philosophical underpinning and its modus operandi, let us now turn to look, more directly, at some of its work on racism in football.

Manufacturing consent: the making of Eliminating Racism from Football

The backdrop to Labour's Task Force on racism in football was, of course, the Labour Party's implemented commitment to a public inquiry into the racist murder in 1993 of black South London teenager Stephen Lawrence. The inquiry was first established in July 1997, at around the same time that the information-gathering exercise of the Football Task Force began. Due to the seriousness and sheer breadth of the investigation into the death of Stephen Lawrence, the inquiry's main findings and recommendations were not published until February 1999,47 almost one year after the publication of the Football Task Force report, Eliminating Racism from Football, in March 1998. The Task Force was directed 'to make recommendations on appropriate measures to eliminate racism from football and encourage wider participation by ethnic minorities, both in playing and spectating'.48 Its core working group thus embarked on a series of regional visits to consult with, among others, fans, officials, police and stewards, community and anti-racism projects, local authority representatives, academics and those involved in playing and administering local football. Following the rather mixed response to its launch and the publicly expressed concerns about its prospects for achieving consensus on other issues, the initial Task Force focus on racism was, in part, precisely a result of the recognition of these tensions and a determination to try to build consensus within the group from the outset. In this context, understanding and opposing racism in football was actually deemed to be remarkably noncontentious, as administrator Andy Burnham recalls:

'No one is 'for' racism in football. The idea was to build a consensus and move on from there. Get people working around an issue where, in theory at least, there is common ground. That was the idea: to build a way of working that developed 
trust and got people together, then finally to tackle the 'thorny' issues. That was the theory'.49

Much is made clear in these comments. First, as Burnham points out, it was naturally assumed that those involved in the Task Force obviously harboured no racist sentiments themselves, a dubious start. As Paul Connolly points out, 50 it is not just overt racist attitudes and practices that constitute racism: it is also the subtle ideas and processes that maintain and reproduce racialization. Second, and following on from this, it was assumed that consensus might be quite easily achieved on the nature of the racism 'problem' within football and how to address it. Third, dealing with racism was thought unlikely to involve the disruption of any of the key structural features of the sport or its power relations. Fourth, addressing racism in football was deemed unlikely to require much in the way of resources and expenditure. Fifth, the causes and sources of racism in the game were liable to be easily identifiable and 'out there', rather than institutionalized within the sport. Finally, the existence of the newly formed independent Kick It Out anti-racism campaign*/an initiative already funded by football*/meant that racism might represent a relatively easy target for the new body. The Task Force could, therefore, 'tap into' an already established framework and ongoing processes and practices in national and anti-racist campaigns. For Piara Powar at Kick It Out this meant:

'In terms of racism I think they [the Football Task Force] felt the key issue was ... that there is an easy answer to [it]. You know: 'There has been a lot of progress made already, so we can get the Task Force up and running through some easy hits, good media publicity.' And there is widespread cross-party, multinational support for the idea that we need to tackle some of the problems of racism in the game'.51

This notion, assumed by the Task Force, that defining and dealing with racism in football was a matter beyond contention was soon exposed and challenged by a number of its academic interviewees. Their attempts to offer evidence that would broaden conceptualizations of the problem*/to encompass, for example, heterogeneous racisms in football, racisms that operated quietly inside football clubs and bodies, as well as among fans and on the pitch*/were treated with a mixture of mystification and hostility by a significant section of the Task Force membership. 52 Similarly, at the evidence-gathering stage and in discussions in the main Task Force group, attempts to explore how issues of institutional racism might limit opportunities in the game for members of minority ethnic communities were often rebuffed or played down. These more complex and sophisticated conceptualizations of the way in which racism might operate within the relatively 'closed' processes and practices of organizations at an institutional level were to feature strongly in the narrative of the findings and recommendations of the Stephen Lawrence inquiry published in February 1999. However, racism in football seemed to be regarded by Task Force members as part of a much broader problem of anti-social behaviours perpetrated, mainly, by young, ill-educated, lower-class white male fans. Andy Burnham himself was well aware of the constraints posed by this limited understanding.

'There was a strong feeling */well, many times it was said: 'This is society's problem, this is not our problem.' There was also that: 'Why does everyone focus on this, as if it is football's 
making?' That was often the line that came from the football authorities. Clubs, yeah, I think they think racism is a problem that arrives at the ground on a Saturday afternoon. It's not a problem they should be dealing with Monday to Friday, in how they recruit staff and what goes on in the dressing room as well'.53

This narrow approach to conceptualizing racism and racial exclusion within English football is, arguably, rooted in the normative 'whiteness' of its core structures: a 'whiteness' that helps account for patterns of racialized exclusion that inform playing, spectating, administration, employment and wider issues of 'representation' within football clubs and the game's governing bodies.54 The unconscious 'denial' of these facts within the Task Force inevitably limited the parameters of its own debates around racisms and their impact on the game, thus avoiding any possibility of a more reflexive gaze: one better aimed, perhaps, at looking within the game's administrative core. Moreover, this dual tendency*/to locate racism and its causes, on the one hand, beyond the parameters of the sport (and therefore beyond any useful remedial work within football), and, simultaneously, to attempt to 'contain' it within the behavioural confines of the actions of a small minority of fans*/undoubtedly weakened the credibility of the Task Force among both practitioners and academics concerned with addressing racism in the professional game. But for those people involved mainly in local football, the new body at least invited a public airing*/and a hearing by the elites*/of concerns about the lack of effective action to deal with football racism at the grassroots. For representatives of a mainly black (African-Caribbean) local football club in Leicester, for example, the visit by the Task Force to the city in 1997 offered a welcome opportunity to step outside local systems of accountability and redress, networks that often punished examples of black resistance and complaint. In these terms, the Task Force at least gave the opportunity to stand up and say how it was.

'We never had an opportunity before, prior to the Task Force coming. If you stood up and challenged the FA you were singled out as a troublemaker. You would suddenly find that your organization started to experience difficulty in the most simplistic of environments, such as match officialdom. So the Task Force broke down that initial barrier and made the football authorities sit up and take notice. More importantly people were, for the first time, in the arena where you couldn't be penalized for your views'.55

Kick It Out also made an incisive and wide-ranging submission to the Task Force on just these sorts of matters: on the institutional barrier that exists in parts of England between local football and the professional game that, according to Kick It Out, remains among the main causes for the near exclusion of British-born Asians from professional football and impedes the progression of black ex-players into coaching and management positions.56 Reflecting, later, on the Task Force and its impact, Kick It Out campaign coordinator Piara Powar articulated a by now familiar ambivalence about its operation and effects.

'It was our first opportunity to engage with government, if you like. . . and we wanted to seize the option of engagement. Nevertheless, like many things related to government it would inevitably be a process which, in some way, could be accused of [being] a fudge, or of being a very broad, generalized approach to the issue that wouldn't, necessarily, make any core or productive recommendations. There was that sort of positive looking forward to it, tinged with some scepticism'.57 
In March 1998, Eliminating Racism from Football was finally published and featured twentyeight recommendations, many linking the grassroots with the professional game. The report undoubtedly marks a unique moment in the history of official responses to racism in English football, and signalled an important policy lead in advance of almost every other country in Europe. It offered a series of targeted recommendations for the FA and for county FAs for dealing, more appropriately and more transparently, for example, with incidents of racism on local 'parks' pitches. It also encouraged more grassroots partnership work with local authorities and more FA support for local anti-racist and social 'inclusion' work, in partnership with local agencies. Indeed, in many ways, the Task Force work in this area underpins aspects of the new equity strategy since adopted by the FA. Despite some internal disagreement, the Task Force also recommended that on-field racism at all levels of the sport be reclassified as an immediate red card offence and that professional football clubs review their scouting procedures in order better to recruit young players from their own local minority ethnic communities.

In terms of football spectating, the Task Force recommended changes to legislation on racist chanting and a wholesale review of stewarding procedures, including more training to improve stewards' awareness of what constitutes racism among fans and improving their recourse to legislation for dealing with racist activity inside football stadiums. Professional football clubs were also offered ideas on how better to 'connect' with local minority ethnic communities and how to 'open up' the core structures of clubs in ways that are more in accordance with their own existing equal opportunities policies. Much of this work was to be shaped by the activities and support of an understaffed Kick It Out, and to be achieved through the development of more multi-agency partnerships at the local level. Eliminating Racism from Football received a cautious welcome from the media and fans as well as from organizations and groups dealing with racism within and around the game.58 There was broad approval for its 'technical' work on on-field racism, for changes to legislation on racialized chanting and for the tightening up of ground regulations and stewarding procedures. However, prosecutions for individual acts of spectator racism continued to remain at very low levels, and were still at odds with other measures of actual levels of fan racism.59 The report offered a useful framework and a stimulus for more local action against racism, and a small number of local projects even used it as a template for plans to monitor and address racism problems, at both professional and amateur levels of the sport.60 But the report was greeted with an air of 'weary pragmatism' by some established campaigners: its carefully worded, occasionally vague and slippery recommendations strongly evoked the detailed and painful negotiation and renegotiation processes involving the football authorities and government that gave birth to them. Getting the racism issue 'on the agenda' at these levels was something of a step forward; but achieving incisive, relevant and practical policies and an on-going commitment aimed at dealing effectively with racism inside professional football clubs, as well as in the stands and on the parks, well, that was something else. Workers in this area were, correspondingly, 'realistic' about the report's conclusions, its omissions and its likely effects.

'I think, unquestionably, the whole process was one where, inevitably, some of the starker recommendations and some of the starker observations were going to be watered down. Generally, the way we [Kick It Out] saw it was that the report covered, very well, some of the basic problems and offered some of the basic 
solutions to those problems. But in terms of addressing institutionalized problems of racism*/in terms of addressing things like the lack of Asian players, black managers and so on*/it had very little to say on those issues'.61

Piara Powar's comments were echoed elsewhere. For Les Back, Tim Crabbe and John Solomos, it was the lack of specificity in many of the Task Force recommendations and the non-recognition of institutional barriers to inclusion by the games' governing bodies and by professional football clubs*/especially with respect to issues of representation and equity*/that rendered such proposals relatively ineffective. Resistance, or a lack of understanding of the ways in which the normalization of whiteness lies at the centre of the structural make-up of football's institutions, and the concomitant problematization of 'otherness' within these rigid monocultural frameworks, meant the intervention of the Task Force itself was monolithic, thus limiting its scope as a tool for radical structural change in the game.62 Even local football representatives, who had, initially, been lifted by the Task Force's visits and by its determination to listen to grassroots' voices, argued that its recommendations ignored many of the real concerns they had expressed about racism in grassroots football cultures.

'In hindsight, to look back in the context in which they [concerns about racism] were noted, the way clever linguists are able to dilute the depth of feeling [in] the report and highlight a number of main issues to do with access, opportunities, feelings of belonging and being a part of the football fraternity as an ethnic minority, as black and Asian people. However, [they do so by] not saying enough about the draconian, institutionally discriminatory, covert practices that were going on'.63

Institutionally, of course, the make-up of the Task Force meant it was already effectively 'sealed off' from addressing some of the key policy questions about racism in the sport. Task Force contributor and black Observer journalist Emma Lindsey was unimpressed by its outcome, which was in her view:

'A palliative document, so bland as to be innocuous. So innocuous as not to bother too much the brows of the people who really matter: those who sit in football's boardrooms, shuffle along the corridors of Lancaster Gate [then the FA head-quarters] and, ultimately, control the way the nation's game is played, on and off the pitch'.64

Findings from an evaluative research report on the effects of the Task Force recommendations at professional clubs in England and Wales also suggested only a limited and patchy response at best.65 Racism in local football*/and some of the local policies for dealing with it*/seemed like an enduring difficulty, especially because the federated structure of the FA offers a high level of autonomy and independence to its representatives at the local level.66 New equity strategies emanating from the national FA may offer a new direction in this regard, but implementation of FA policy at regional and local levels of the game is likely to remain problematic. Given popular perceptions of county FAs and their relatively 'closed' elective processes*/ and also the generally diminishing commitment to exacting voluntary activity of this sort*/it is hardly surprising that so few county FA officials are young, female or drawn from minority ethnic backgrounds.67 'Positive action' to make more representative the administrative structures of the FA at local and national levels is 
also part of the new equity agenda at the FA, but exactly how such strategies are eventually implemented in the future remains, very much, in the balance.

Some conclusions: neither Mecca nor Madrid

The 'philosophical' underpinnings and the make-up of New Labour's Football Task Force, allied to its simplistic and narrow conceptualization of the racism problem in English football, reveals a tendency to define and reproduce both 'race' and racism as unitary phenomena. This approach negates any broader conceptualizations of the problem: ones that recognize the complexity and diversity of racisms, their often contradictory character in professional sport and also the extent to which late-modern identities are complex and always 'in process'.68 As such, we would contend that, while football crowds in England have grown less overtly racist, New Labour has actually done relatively little to disrupt the centrality and relative permanence of white hegemonic structures within the governance and administration of English football. This means that even in late-modern cultures, in which identity construction is contingent, complex and fluid, members of minority communities are still likely to have to show willingness to subordinate important aspects of their own increasingly 'glocalized' minority identities in order to make progress in institutionally 'closed' domains such as football governance.69 It was, of course, designed to be this way: New Labour's Task Force was unrepresentative, lacked statutory powers, was packed with white football administrators and favoured poorly monitored, self-regulation for football from the outset. As Piara Powar of Kick It Out argues:

'What was clear is that there is very little clarity in terms of how the report was going to be driven forward and that should have been set out at the beginning of the process, or somewhere along the process so that it was clearer to people.... If those things alone are implemented it takes us down the road of tackling some of these problems quite significantly. But that didn't happen. It seems to us that the report sat on the shelf for a long time. There was no continuing government drive to make sure it was implemented. Engaging with government on it was very difficult'.70

In 2002, with the approval of the government and the football authorities*/ but with some opposition from organized football fans*/a new body, the Independent Football Commission (IFC), was finally established, as recommended by the Football Task Force. The IFC is funded by the game to monitor and evaluate how the football authorities exercise their jurisdiction over the football industry, shaped by a strongly Blairite framing focus on the need for 'customer care'. Like the Football Task Force that spawned it, the IFC has no statutory powers, even to enforce its own proposals and recommendations. In its Annual Report for 2003, the IFC reported on issues of racism in the game, specifically to follow up on progress since the publication of Eliminating Racism from Football. The IFC emphases here were, determinedly, on customer service issues, rather than on a wider sense of policy and strategy but, five years on from the initial Task Force intervention on racism, the report still makes uncomfortable reading for those concerned with the English game. The IFC had some positive things to say about the FA's new equity strategies, but was rather more critical on issues of ethnic minority representation and employment in the English game and on the clear failure of English professional clubs to recruit successfully from ethnic minorities*/especially from British Asian communities*/either full-time administrative staff, 
players or spectators.71 Indeed, a Commission for Racial Equality report published in 2004 claimed that 79 per cent of all Premiership clubs still recruit their management and administrative staff*/overwhelmingly white staff, of course*/on an informal basis and concluded that 'the football industry has failed to seriously address racial equality issues' .72

The public outcry in England over 'monkey' chants at a football match in Spain in 2004 tells us something about changes in English football fan culture and, certainly, about wider changes in British society. But it probably also alludes to a cynical awareness on the part of the football authorities in England of the public relations benefits of being seen to respond loudly and decisively (albeit a little sanctimoniously) to such incidents. It is, of course, much easier for the FA and the Premier League to project racism as exclusively the property of fans*/especially 'foreign' fans*/who have been less 'civilized' by football-sponsored antiracism campaigns than have their English counterparts, than it is to understand and address the complexity and diversity of multiple and institutionalized forms of racial exclusion embedded within the English game and its structures. The response in Britain to events in Madrid arguably smacks of dangerous hypocrisy and risks reducing the debate about 'success' in combating racism in English football to monitoring a weekly ninety-minute 'race' silence from football supporters, rather than focusing on the existing exclusionary practices of professional clubs and governance bodies in England. This current public discourse about 'football racism' in England strongly resembles, in fact, that which was once dominant within the Football Task Force itself and which was so rigidly pursued by the most powerful bodies within this 'partnership'. Indeed, the lack of a direct challenge from Labour to the embedded nature of white hegemonic structures withinprofessional football in England meant that the Football Task Force workcould effectively short-circuit precisely the kinds of debates and subsequent actions that could*/and that would be needed to*/effect real change in this area. The appearance of change is, after all, not change at all. As ex-England player John Barnes commented soon after the events in Spain in 2004: 'Because we don't hear it anymore [among fans] we think we're getting rid of racism [in English football]. Please, let's not all believe we're much better [than Spain] in this country.'73 Quite.

Steven Bradbury is Research Associate at the Institute of Youth Sport within the School of Sport and Exercise Science at Loughborough University. He is presently conducting research into sports voluntarism among young people in England. His other research interests include racism and anti-racist strategies in English football and he chairs Port Vale Football Club's antiracism group Valiants against Racism. He is the author of The New Football Communities (University of Leicester 2001).

John Williams is Director of the Centre for the Sociology of Sport at the University of Leicester, and has been researching football fans and fan cultures in the United Kingdom over a number of years. His recent publications include The Liverpool Way (Mainstream Press 2003). He also chairs the anti-racism football group Foxes against Racism in Leicester. 73 Quoted

1. Reported in S. Lowe, 'Nation turns the blame on English being over-sensitive', Daily Telegraph , 19 November 2004, 53. In England, earlier in 2004, the well-known television football pundit and ex-manager Ron Atkinson had himself been instantly sacked for 
using the word 'nigger' in an aside caught by microphones left 'live' at the end of a broadcast.

$2 \mathrm{~J}$. Carlin, 'Spain must take prompt action or stain left by Bernabeu disgrace will remain', Independent, 19 November 2004, 61.

3 Kick It Out is the national football anti-racism campaign in England that works with the Football Association (FA), the national team and professional and non-professional clubs.

4 D. Taylor, 'Aragones attacks English "wolves"”, Guardian, 17 November 2004, 36.

5 See, for example, J. White, 'This shocking abuse is a weekly ritual', Daily Telegraph, 19 November 2004.

6 For an explanation citing globalization and racism in Europe, seeW. Hutton, 'Caught in a circle of hate', Observer, 21 November 2004, 28; for one citing the effects of immigration in Spain, see G. Tremlett, 'Immigration surge fuels racism in Spain', Guardian, 20 November 2004, 19.

7 See G. Balague, 'A lot of noise, but very little self-analysis', Observer, 21 November 2004,7 . These clearly premeditated incidents seem unlikely to have been the work of 'committed racists', so they do raise key questions concerning Long and McNamee's important attempt to develop a 'racist register' for sport; see J. Long and M. J. McNamee, 'On the moral economy of racism and racist rationalizations in sport', International Review for the Sociology of Sport, vol. 39, no. 4, 2004, 405/20. 8 As the football magazine When Saturday Comes pointed out (no. 215, January 2005, 4), tabloid newspapers in England chastised Spain for its football racism while simultaneously running racist stories about asylum-seekers and mythic 'Gypsy' settlements in Britain. Gordon Taylor, the chief executive of the Professional Footballers' Association, the players' union in England, argued in the British broadsheets that the England team should have vacated the pitch in Madrid. Referee Rene' Temmink had recently abandoned a Dutch league match between ADO Den Haag and PSV Eindhoven after eighty minutes because of repeated antisemitic chanting by the home fans.

9 See K. Mitchell, 'I was a racist*/but football changed me', Observer, 28 November 2004, 8.

10 E. Cashmore, 'Beware the banana skin', Independent on Sunday, 21 November 2004, 16. 11 Boa Morte claimed that, when he had reported a fellow professional player in England for calling him a 'black cunt' during an FA Cup match in January 2003, he was accused of 'playing the race card', and no charges were brought by the FA; reported in A. Kessel, 'Home is where the hurt is', Observer, 21 November 2004, 6.

12 Five men were later arrested and a twenty-two-year-old local man was fined $£ 1,000$ and banned from football grounds in England until 2009; see P. Hurst, 'Football fan is banned for racially abusing opposition player', Independent, 25 November 2004, 6. 13 Piara Powar of Kick It Out made this comment about the fine imposed by Fifa; see 'Spain fined for racist chanting', 21 December 2004, available on the BBC News website at http://news.bbc.co.uk/sport1/hi/football/internationals/4110135.stm (viewed 26 October 2005).

14 Blair's comments were reported in D. Pilditch, 'Blair puts the boot into Spanish racists', Daily Express, 19 November 2004, 9.

15 D. Butler and D. Stokes, Political Change in Britain (London: Macmillan 1974).

16 T. Mason, Association Football and English Society, 1863/1915 (Brighton: Harvester Press 
1980).

17 A. Tomlinson, 'North and South: the rivalry of the Football League and the Football Association', in J. Williams and S. Wagg (eds), British Football and Social Change (Leicester: Leicester University Press 1991).

18 N. Fishwick, English Football and Society, 1910/1950 (Manchester and New York: Manchester University Press 1989), 138.

19 See J. Hargreaves, Sport, Power and Culture: A Social and Historical Analysis of Popular Sports in Britain (Cambridge: Polity Press 1986), 92/3, and S. Jones, Sport, Politics and the Working Class (Manchester and New York: Manchester University Press 1988), 122. This position was occasionally challenged, for example, in the Trade Union Congress's protests about the visit of Nazi Germany to play England in Jewish North London in November 1935; see Fishwick, English Football and Society, 139.

20 Jones, Sport, Politics and the Working Class, 18.

21 Fishwick, English Football and Society, 150.

22 Rt Hon. Lord Justice Taylor, The Hillsborough Stadium Disaster, 15 April 1989: Final Report (London: HMSO 1990).

23 On 'new' football and the FA Premier League, see J. Williams, Is It All Over: Can Football Survive the FA Premier League? (Reading: South Street Press 1999), and A. King, The End of the Terraces (Leicester: Leicester University Press 1998).

24 P. Davies, All Played Out: The Full Story of Italia '90 (London: Heinemann 1990). Ibid., 244. For more on England football fans and racism in the 1980s, see J. Williams, E. Dunning and P. Murphy, Hooligans Abroad (London: Routledge and Kegan Paul 1984).

26 B. Carrington, 'Football's coming home, but whose home?', in A. Brown (ed.), Fanatics! (London: Routledge 1998). For more on Blair and 'cool Britannia', see K. Davey, English Imaginaries: Six Studies in Anglo-British Modernity (London: Lawrence and Wishart 1999).

27 R. Holt and T. Mason, Sport in Britain 1945/2000 (Oxford: Blackwell 2000), 155.

28 R. Levitas, The Inclusive Society? (London: Macmillan 1998), 113. For more on the new marketing trajectory of English football, see Football Association, Blueprint for Football (London: Football Association 1991).

29 S. Hall, 'New ethnicities', in J. Donald and A. Rattansi (eds), 'Race', Culture and Difference (London: Sage 1992), 252.

30 Davey, English Imaginaries, 17.

31 For more on the contingent inclusion of ethnic minority fans during Euro '96, see L. Back, T. Crabbe and J. Solomos, The Changing Face of Football: Racism, Identity and Multiculture in the English Game (Oxford: Berg 2001).

32 J. Cunningham and T. Pendry, Charter for Football (London: Labour Party 1996).

33 A. Brown, 'The Football Task Force and the regulator debate', in S. Hamil, J. Mitchie, C. Oughton and S. Warby (eds), Football in the Digital Age: Whose Game Is It Anyway? (Edinburgh and London: Mainstream Publishing 2000), 57.

34 Quoted in Brown, 'The Football Task Force and the regulator debate', 69.

35 A. Giddens, The Third Way: The Renewal of Social Democracy (Cambridge: Polity Press 1998). For a critique of Giddens and the 'third way', see P. Cammack, 'Giddens's way with words', in S. Hale, W. Leggart and L. Martell (eds), The Third Way and Beyond (Manchester: Manchester University Press 2004).

36 Levitas, The Inclusive Society? , 117. 
37 Brown, 'The Football Task Force and the regulator debate', 62.

38 Andy Burnham, interview with the authors, 12 April 2002. All the semi-structured interviews with Task Force members quoted here were conducted as part of an ESRC CASE studentship in partnership with the Professional Footballers' Association. For more information on interviewees and methodology, see S. Bradbury, 'Racisms and Anti-Racism in English Football', Ph.D. thesis, University of Leicester, 2003.

39 Brown 'The Football Task Force and the regulator debate'.

40 Andy Burnham, interview with the authors, 12 April 2002.

41 Adam Brown, supporters' Task Force representative, interview with the authors, 5 April 2002.

42 See, for example, I. Ridley, 'Softly, softly, Task Force ... I think I'm being used', Observer Sport, 12 December 1999, 2.

43 See V. Choudhary, 'Task Force split over money', Guardian, 22 December 1999, 22.

44 Andy Burnham, interview with the authors, 12 April 2002.

45 Gordon Taylor, interview with the authors, 8 May 2002.

46 Adam Brown, interview with the authors, 5 April 2002.

47 William Macpherson, The Stephen Lawrence Inquiry: Report of an Inquiry by Sir William Macpherson of Cluny, Cm 4262-I (London: Stationery Office 1999).

48 Football Task Force, Eliminating Racism from Football (London: Football Task Force 1998), 7.

49 Andy Burnham, interview with the authors, 12 April 2002.

50 P. Connolly, 'Racism and young girls' peer group relations: the experience of South Asian girls', Sociology, vol. 34, 2000, 499/519 (503).

51 Piara Powar, interview with the authors, 9 May 2002.

52 See Back, Crabbe and Solomos, The Changing Face of Football , and J. Garland and M. Rowe, Racism and Anti-Racism in Football (London: Palgrave 2001).

53 Andy Burnham, interview with the authors, 12 April 2002.

54 C. King, Offside Racism: Playing the White Man (Oxford: Berg 2004).

55 Jos Johnson, Highfield Rangers FC, interview with the authors, 5 February 2002.

56 Kick it Out, 'Submission to the Football Task Force', 1998. See also J. Bains and R.

Patel, Asians Can't Play Football (Solihull: Asian Social Development Agency 1995) and

D. Burdsey, 'Obstacle race? "Race", racism and the recruitment of Asian professional footballers', Patterns of Prejudice, vol. 38, no. 3, 2004, 279/300.

57 Piara Powar, interview with the authors, 9 May 2002.

58 See M. Brown, 'Forcing the issue', When Saturday Comes, no. 148, 1998, 22/3, and E. Lindsey, 'Task Force fails to really put the boot in on racism', Observer Sport , 29 March 1998, 4.

59 Annual National Criminal Intelligence figures on recorded racist offences at football matches are routinely highlighted by anti-racism groups as underplaying the problem of football racism; such data tend to rely on fan reporting. National survey data on football fans suggest that incidents of racism are much more widely spread at football. See J. Williams, FA Premier League National Fan Survey (Leicester: University of Leicester and FA Premier League 2001).

60 The Foxes against Racism group in Leicester, for example, began as a response to the Task Force agenda and is still highly active in the city today.

61 Piara Powar, interview with the authors, 9 May 2002.

62 Back, Solomos and Crabbe, The Changing Face of Football , 201. 
63 Jos Johnson, interview with the authors, 5 February 2002.

64 Lindsey, 'Task Force fails to really put the boot in on racism'.

65 S. Bradbury, The New Football Communities: A Survey of Professional Football Clubs on Issues of Community, Ethnicity and Social Inclusion (Leicester: Sir Norman Chester Centre for Football Research, University of Leicester 2001).

66 J. Long, K. Hylton, M.Welch and J. Dart, Part of the Game: A Report Prepared for Kick It Out at the Centre of Leisure and Sport Research (Leeds: Leeds Metropolitan University and Kick It Out 2001).

67 A Commission for Racial Equality (CRE) survey, Racial Equality in Football (London: CRE 2004), reported that 13 of 810 local county FA council members (less than 2 per cent) were black or of South Asian origin.

68 Burdsey, 'Obstacle race?', 298. See also Bradbury, 'Racisms and Anti-Racism in English Football'.

69 Burdsey, 'Obstacle race?', 288. Colin King, in Offside Racism, makes this point strongly, but he also seems, to us, to operate with what Long and McNamee call an on/off conceptualization of racism that, in turn, is predicated on a rather essentialized notion of race and difference. We prefer Burdsey's more complex approach to 'race' and identity construction, but we would also suggest that Burdsey overplays the structural importance of subjective interpretations of identity among young British Asian footballers.

70 Piara Powar, interview with the authors, 9 May 2002.

71 Independent Football Commission, Annual Report 2003 (Middlesbrough: University of Teeside 2003). Significantly, the IFC was forced to defend media charges, prior to publication, that it was claiming that the game was 'racist', but commented that the continuing perception that English football is 'institutionally racist' is important. IFC member and former Tottenham and Manchester United footballer Garth Crooks commented: 'For change to be meaningful it has to be radical. This report is not about a token black face here and there'; quoted in 'Report critical over racism', 10 February 2004, available on the BBC News website at http://news.bbc.co.uk/sport1/hi/ football/3476161.stm (viewed 27 October 2005).

72 Commission for Racial Equality, Racial Equality in Football , 42. Burdsey, in 'Obstacle race?', argues that his Asian subjects suggest that the separate development of Asian leagues at amateur levels is one of the reasons for their lack of progress in the professional game, though there is no evidence at all to suggest that more progress is made by Asians in areas where amateur football is mixed.

73 Quoted in Kessel, 'Home is where the hurt is'. 